Journal of

Accident and

Emergency

Medicine 1994

11, 175-177

\title{
What should doctors wear in the accident and emergency department? Patients' perception
}

\author{
D.BOON \& J.WARDROPE
}

Department of Accident and Emergency Medicine, Northern General Hospital, Sheffield

\section{SUMMARY}

In many accident and emergency (A\&E) departments doctors still wear white coats or their ordinary clothes, rather than a type of uniform, which, should it become contaminated, can be changed easily for a clean uniform. Before a change of clothing to a uniform could be considered in an inner-city A\&E department, a study was carried out to assess the public's perception towards different styles of dress. Three hundred and twenty-nine questionnaires were returned by minor injury patients requiring a radiograph. The study was carried out over 3 weeks in January 1993. Each week a different style of dress was worn: week 1 - white coats, week 2 - normal clothing and week 3 - theatre greens. The majority of patients thought that style of dress was important but did not alter their attitude towards the A\&E medical staff. Therefore, there is no reason why doctors should not wear a more appropriate uniform that can be changed easily when contaminated.

\section{INTRODUCTION}

It is a common public perception that doctors in hospital should wear white coats and such images are reinforced regularly on television. ${ }^{1}$ Previous literature has found that patients prefer doctors to dress traditionally with shirt and tie, short hair, dresses, white coats, name tags and stethoscope. ${ }^{2-6}$ These studies also showed that patients thought that the traditional styles of dress inspire confidence, especially in the older age group. Doctors wear white coats for easy recognition by colleagues and patients, for carrying equipment and in an attempt to keep clothes clean. ${ }^{7}$

Recent studies have shown that white coats offer little protection to staff in an A\&E department and also that they quickly become contaminated and are a potential source of infection. ${ }^{8,9}$
This concern has led some authors to advise that staff in A\&E departments should be provided with special uniforms to reduce the risks of contamination with blood or other bodily fluids.

Given the importance attached to the appearance of doctors in previous studies, it was thought necessary to assess the potential effects of public perception, before implementing a change in the style of dress.

\section{METHODS}

Over a 3-week period in January 1993, the medical staff in the A\&E department wore different styles of dress on each individual week. During week 1 , the staff wore white coats (WC), during week 2 ordinary clothes (OC; collar tie/dress), and during week 3 they wore operating theatre 'greens' (TG).

Patients attending the minor injuries area, who required a radiograph, were given a questionnaire by medical staff before they went to the radiograph department, which was collected on their return (Fig. 1). Children were not included in the study.

\section{RESULTS}

A total of 329 questionnaires were returned during the course of the study. Table 1 lists the numbers of responses in each group, along with replies to the first five questions. Table 1 also shows no significant differences in the age or sex distribution between the groups. There was no significant difference in the numbers of patients who described the mode of dress as unclean, unprofessional or scruffy.

Some patients found it difficult to identify the type of dress worn by the doctor. In the WC period, $1 \%$ of patients failed to identify what the doctor was wearing, during the period when TG were worn, $9 \%$ failed to do so and during the period when ordinary clothes were worn $17 \%$ failed to do so. Most of the incorrect responses indicated that the patients 
D. Boon \&

J. Wardrope

\section{PATIENT SURVEY \\ ACCIDENT AND EMERGENCY DEPARTMENT}

Could you spare 2 more minutes of your time to complete the questionnaire and help us to improve the department.

Your answers will be confidential and the results will not identify any patient/parent.

\section{PLEASE RING YOUR ANSWER}

1. Could you give a few details-

$$
\text { Your age- Male/Female }
$$

2. Do you think a doctor's appearance is important?

$$
\text { Yes/No }
$$

3. Was your doctor wearing

Casual clothes/White coat/Green uniform/Did not notice

4. Was the doctor's appearance

$\begin{array}{ll}\text { Clean and tidy } & \text { Yes/No } \\ \text { Professional looking } & \text { Yes/No } \\ \text { Scruffy } & \text { Yes/No }\end{array}$

5. Did the doctors appearance change your opinion of them?

$$
\text { Yes/No }
$$

6. How do you think that doctors in the Accident Department should dress?

Casual clothes/White coats/Green uniforms/Don't mind

7. On a scale of $0-10$ how would you rate the professional appearance of the doctor-

not professional very professional

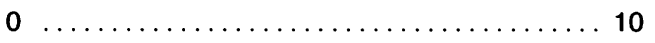

THANK YOU FOR YOUR HELP. PLEASE RETURN QUESTIONNAIRE TO YOUR DOCTOR

Fig. 1. Questionnaire given to patients requiring a radiograph.

thought that the doctor was wearing a white coat.

Patients were then asked how they thought doctors should dress. During week 1 they either did not mind or preferred white coats. In the other two

Table 1.

\begin{tabular}{lccc}
\hline & White coat & $\begin{array}{c}\text { Ordinary } \\
\text { clothes }\end{array}$ & $\begin{array}{c}\text { Theatre } \\
\text { greens }\end{array}$ \\
\hline $\begin{array}{l}\text { Total returned } \\
\text { questionnaires } \\
\begin{array}{l}\text { Appearance not } \\
\text { important }\end{array}\end{array}$ & 73 & 131 & 119 \\
$\begin{array}{l}\text { Incorrectly } \\
\text { identified dress }\end{array}$ & $1 \%$ & $23 \%$ & $16 \%$ \\
$\begin{array}{l}\text { Unclean } \\
\text { Unprofessional } \\
\text { Scruffy }\end{array}$ & $1 \%$ & $17 \%$ & $9 \%$ \\
\hline
\end{tabular}

weeks the majority did not mind but there were high preferences for the dress worn at that time and white coats in almost equal percentages (Table 2). In each group $11 \%$ felt the style of dress changed their opinion of the doctor. The visual analogue

Table 2.

\begin{tabular}{lcccc}
\hline $\begin{array}{l}\text { Public's idea } \\
\text { of what } \\
\text { doctors } \\
\text { should wear }\end{array}$ & $\begin{array}{c}\text { Week 1 } \\
\text { wearing } \\
\text { ordinary } \\
\text { clothes }\end{array}$ & $\begin{array}{c}\text { Week 2 } \\
\text { wearing } \\
\text { theatre } \\
\text { greens }\end{array}$ & $\begin{array}{c}\text { Week 3 } \\
\text { wearing } \\
\text { white } \\
\text { coats }\end{array}$ & $\begin{array}{c}\text { Do not } \\
\text { mind }\end{array}$ \\
\hline $\begin{array}{l}\text { White coats } \\
\text { Ordinary } \\
\text { clothes }\end{array}$ & $1 \%$ & $1 \%$ & $61 \%$ & $37 \%$ \\
$\begin{array}{c}\text { Theatre } \\
\text { greens }\end{array}$ & $1 \%$ & $1 \%$ & $22 \%$ & $56 \%$ \\
\hline
\end{tabular}


What should doctors wear? scale to assess professional appearance showed little discrimination between the groups (averages: week 1 (WC) 9.14, week 2 (OC) 8.98 and week 3 (TG) 8.89).

\section{DISCUSSION}

There has been significant criticism recently over the use of white coats as a mode of dress for doctors in A\&E. However, little thought seems to have been given to the impact that any change in appearance may have on the public's perception of A\&E medical staff. This study shows that the public did not mind the mode of dress worn and that it was mainly clean, tidy and professional, irrespective of whether the doctors were wearing white coats, theatre greens or ordinary clothes.

There is a strong public perception that doctors wear white coats and this study supports this in that during the weeks when white coats were not worn some patients assumed that they were being worn. This perception is strongly reinforced by media images and is going to be hard to change. It indicates that if other forms of clothing are worn in the A\&E department, then it is very important that doctors can easily be identified by badges or even badges plus the word 'doctor' written on a uniform.

\section{CONCLUSIONS}

Patients and relatives who attended the A\&E department did not mind what was worn, thinking all were clean, tidy and professional. Public perception of doctors is one of them wearing white coats, but changing the mode of dress to either uniform or casual clothes, changes this perception. Of the few who still consider white coats the more appropriate wear, there is no evidence to suggest that this is because of untidiness, unprofessionalism or uncleanliness. Perhaps, it is because of the long standing image of doctors and white coats. There is, therefore, no reason uncovered in this study why A\&E doctors should not wear a more appropriate uniform, which is easy to change out of and reduce cross infection.

\section{REFERENCES}

1. Blumhagen D. (1979) The Doctor's white coat, the image of the physician in modern America. Annals of Internal Medicine 91, 111-116.

2. Gjerdingen D.K., Simpson D.E. \& Titus S.L. (1987) Patients' and physicians' attitudes regarding a physician's professional appearance. Archives of Internal Medicine 147, 1209-1212.

3. Colt H.G. \& Solot J.A. (1989) Attitudes of patient and physicians regarding physician's dress and demeanor in the emergency department. Annals of Emergency Medicine 18, 145-151.

4. Sanders L.D., Gildersleve C.D. \& Rees L.T. (1991) The impact of the appearance of the anaesthetist on the patient's perception of the pre-operative visit. Anaesthesia 46, 1056-1058.

5. McKinstry \& Wang (1991) Putting on the style: what patients think of the way their doctor dresses. British Journal of General Practice 41, 275-278.

6. Hennessy N., Harrison D.A. \& Aitkenhead A.R. (1993) The effect of the anaesthetist attire on patients' attitudes. Anaesthesia 48, 219-222.

7. Faraj R. \& Baron J.H. (1991) Why do hospital doctors wear white coats? Journal of Royal Society of Medicine 84, 43.

8. Littlechild P., Macmillan A., White M.M. \& Steedman D.J. (1992) Contamination of skin and clothing of accident and emergency personnel. British Medical Journal 305, 156-157.

9. Wong D., Nye K. \& Hollis P. (1991) Microbial flora on doctor's white coats. British Medical Journal 303, 1602-1604. 